\title{
アルミニウム単結晶の変形挙動に及ぼす ひずみ速度の影響*
}

\author{
向井敏 司*1, 東 健 司*2, 谷村畺 治*2
}

\author{
Influence of Strain Rate on Deformation Behavior \\ of Aluminum Single Crystals
}

\author{
Toshiji MUKAI, Kenji HIGASHI and Shinji TANIMURA
}

\begin{abstract}
The deformation behavior of aluminum single crystals $(99.998 \%$ purity) was investigated using a compression test at room temperature. Static tests $\left(1 \times 10^{-5} \sim 1 \times 10^{-1} \mathrm{~s}^{-1}\right)$ were performed with an Instron machine, and dynamic tests were performed using a Hopkinson pressure bar system. The flow stress of a crystal properly oriented for double slip increases with increasing strain rate in the range of $1 \times 10^{-5}$ to $1 \times 10^{-1} \mathrm{~s}^{-1}$, while that of crystals properly oriented for single slip is independent of strain rate in the same range. Flow stress increases rapidly with increasing strain rate beyond $4 \times 10^{2}$ $\mathrm{s}^{-1}$ for all crystals. From observation with a scanning electron microscope, it is revealed that as the strain increase, the density of slip bands increases and the contrast of slip bands is weakened.
\end{abstract}

Key Words : Impact Strength, Material Testing, Dislocation, Aluminum Single Crystal, Orientation, Slip Bands, Strain Rate Sensitivity

\section{1. 緒 言}

近年の科学技術の進歩にともなう機械の性能の向上 により, 各部材に作用する荷重の種類は静荷重から衝 撃荷重まで様々なものとなってきている．そのため 様々な荷重下での機器の使用の安全性および信頼性を 確保する上で, 素材のひずみ速度に応じた強度を知る ことは重要である.一般に, 機械の部材に使用される 金属は多結晶体であり，ほとんどの素材の機械的性質 に関する研究は多結晶体について行なわれている。し かしながら，基礎的な金属の特性に関する知見を得る ためには，金属が結晶の集合体であることは無視でき ない，それゆえ，各結晶粒の特性および結晶間の界面 すなわち粒界の特性を調べる必要があるものと思われ る。ここで各結晶粒の特性は，さまざまな方位を有す る单結晶について, また, 粒界の特性は特定数の粒界 を有する双結晶等の特性を評価すれば良いものと思わ れる。それらの結果を結び付けて, 多結晶体の変形挙 動, 特に衝撃的に変形させたときの強度等の挙動解明 に応用できるものと考えている，単結晶や双結晶に関

* 原稿受付 平成 4 年 10 月 19 日.

*1 正員, 大阪府立大学大学院 ( 593 堺市学園町 1-1).

*2 正員, 大阪府立大学工学部.
して, 異なる方位における変形挙動の差異や温度依存 性については，数多くの研究がなされているが，それ らは $1 \times 10^{-2} \mathrm{~s}^{-1}$ 以下の比較的低いひずみ速度での評 価が大多数を占める.ところが, 単結晶について, 変形 応力のひずみ速度依存性に関する研究は数少な い(1)〜(3). また，その評価も $10^{-3} \mathrm{~s}^{-1}$ 付近の準静的な低 ひずみ速度の場合と $10^{3} \mathrm{~s}^{-1}$ 付近の高ひずみ速度の場 合についての比較に留まり，ひずみ速度の関数として の評価はされていない.

そこで, 本研究では, 高純度アルミニウムを用いて， 方位の異なる単結晶試験片を作成し, 室温において 1 $\times 10^{-5} \sim 2 \times 10^{3} \mathrm{~s}^{-1}$ の幅広いひずみ速度範囲で圧縮試 験を行うことで,これらの圧縮強度に及ぼすひずみ速 度の影響を調べた。また，表面観察によりひずみ 0.2 に おけるすべり帯間隔を測定し，すべり帯間隔とひずみ 速度の関係について検討した。

\section{2. 実 験 方 法}

$2 \cdot 1$ 試料の準備 本研究で使用した試験片の供 試材は, 純度 $99.998 \%$ の高純度アルミニウムである。 単結晶の作成前に，圧延素材を焼鈍することで加工に よるひずみを除去した。単結晶の作成は, 真空中にて 縦形の Bridgman 法により行い，3 種の方位を有する 
棒状単結晶を準備した，各棒材からの単結晶試験片の 採取は放電加工により行った，試験後の表面のすべり 線観察を容易にするため, 試験片の形状は角柱形状 (高さ $8 \mathrm{~mm}$,一辺 $4 \mathrm{~mm}$ の正方形断面)とした。 また， 形状の違いによる試験誤差を抑えるために試験は，全 ての条件について同一形状および寸法を有する試験片 により行った.また, 各単結晶の方位の測定は, 背面ラ ウエ法により, 圧縮軸方向の方位を測定した。各単結 晶の圧縮軸方位を図 1 に示す。

試験後に試験片表面の観察を行うため,すべての試 験片の表面を\# 1500 のメリーペーパを用いて, 流 水中にて, ほとんど負荷をかけずに研磨した。 その後, 電解研磨を行って表面を鏡面状にするとともに, ペー パ研磨による加工層を除去した。

$2 \cdot 2$ 試験条件すべての試験は室温にて行った。 $1 \times 10^{-5} \sim 1 \times 10^{-1} \mathrm{~s}^{-1}$ の低ひずみ速度範囲における試 験には，インストロン試験機を用いた.また, $4 \times 10^{2} \sim$ $1.2 \times 10^{3} \mathrm{~s}^{-1}$ の高ひずみ速度範囲における試験には, ホプキンソン棒法試験機を用いた。 高速試験機の概略 を図 2 に示す.

また, 試験後に試験片の側面を走査電子顕微鏡

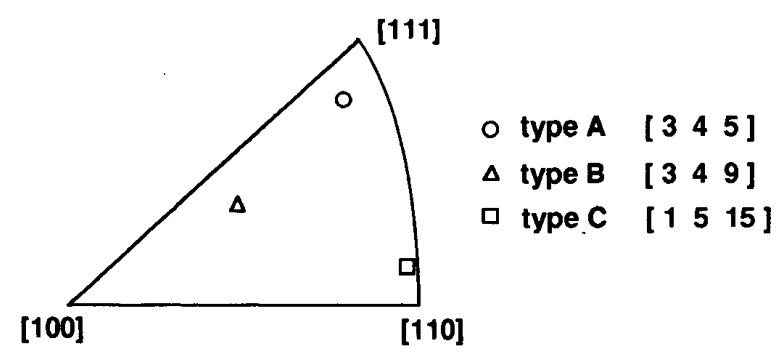

図 1 各単結晶の圧縮軸方位

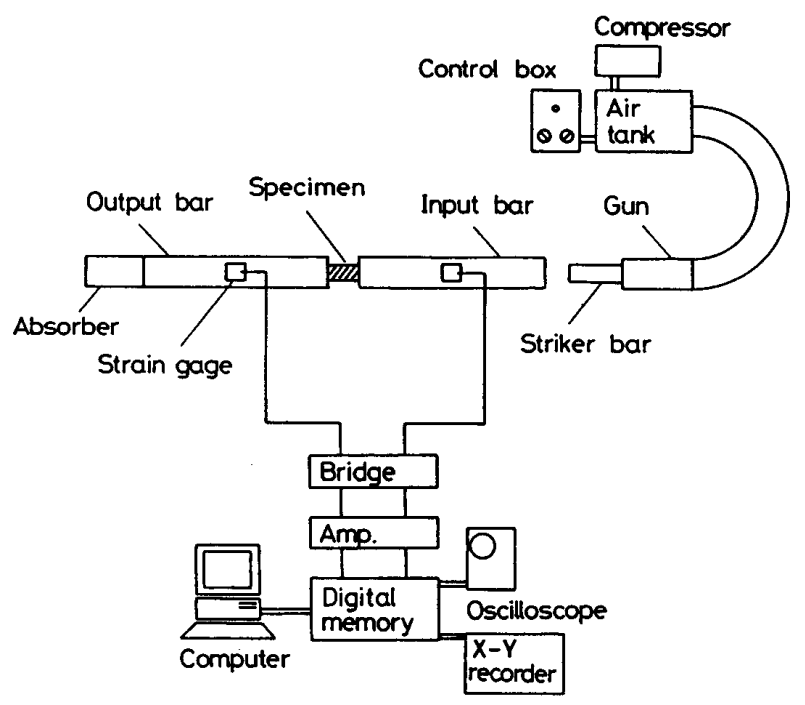

図 2 高速試験機の概略図
(SEM)を用いて観察した。

\section{3. 実 験 結 果}

$3 \cdot 1$ 各方位における圧縮特性［1 111$]$ に近い方 位を有する試験片 (type A)の応力ーひずみ曲線を図 3 に示す,一般に, 単結晶の応力とひずみの関係は, 分解 せん断応力と分解せん断ひずみによって示されること が多い。しかしながら本研究では, 各方位における変 形応力のひずみ速度依存性を評価することをその主た る目的としているため, 変形応力の評価は真応力と真 ひずみの関係について行った. type A の応力ーひずみ 曲線の形状は多結晶アルミニウムの場合にみられるよ うな, 降伏点の判別が困難な, 上に凸の放物線となっ ている.また,ひずみ速度が高くなるに従って, 流動応 力は増加している。

次に, type Bの単結晶試験片の応力ーひずみ曲線を 図 4 に示す.この方位の単結晶についても, type Aの 場合と同様に, ひずみ速度が高くなるに従って, 流動 応力は増加している，ところが, 応力ーひずみ曲線の形

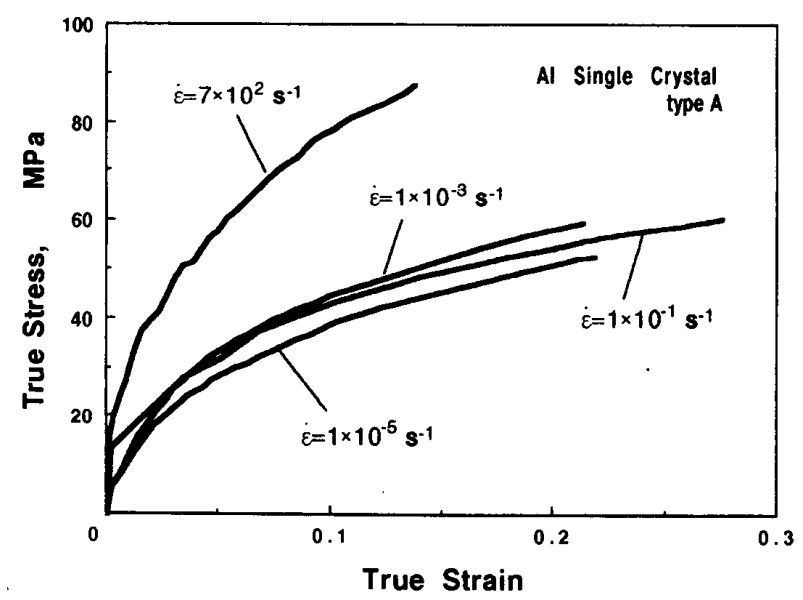

図 3 単結晶 type $\mathrm{A}$ の応力ーひずみ曲線

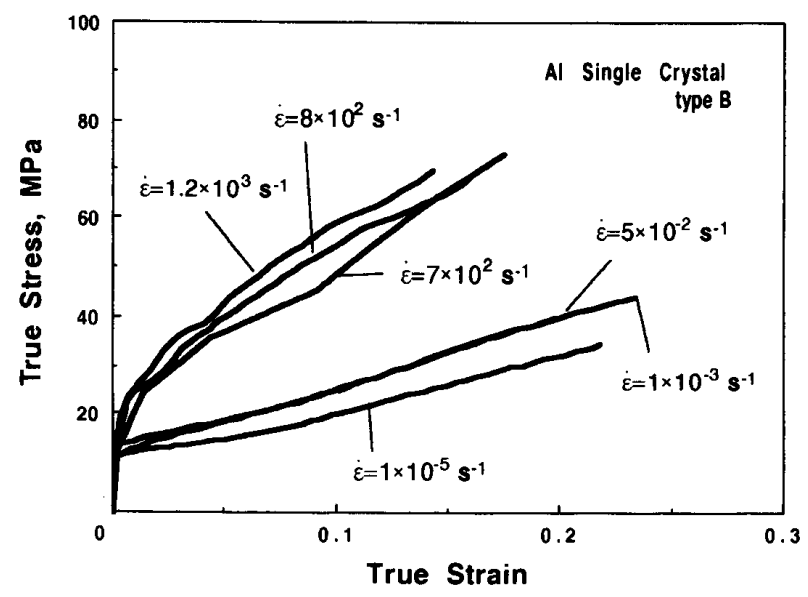

図 4 単結晶 type B の応力ーひずみ曲線 
状は type A の場合とは異なっている。すなわち，低ひ ずみ速度で試験したときは放物線形状とはならずに， 変形初期ではひずみが増加しても流動応力は，ほとん ど変化しない形状となっている，いわゆる，単結晶の 加工硬化曲線における第一段階が明確に現れている. その後, 流動応力は変形とともに徐々に増加し,下に 凸の形状の応力ーひずみ曲線となる。しかし，高ひずみ 速度で試験したときは, type Aの場合と同様に上に 凸の放物線形状となっている。

最後に，［1 111$]$ - [ $\left.\begin{array}{lll}1 & 1 & 0\end{array}\right]$ 境界近傍の方位を有する type Cの単結晶試験片における応力ーひずみ曲線を図

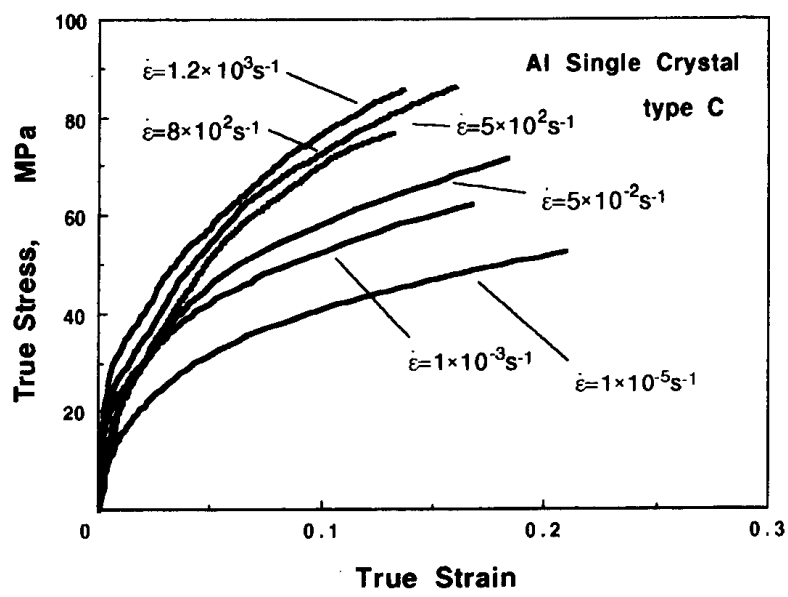

図 5 単結晶 type $C$ の応力ーひずみ曲線

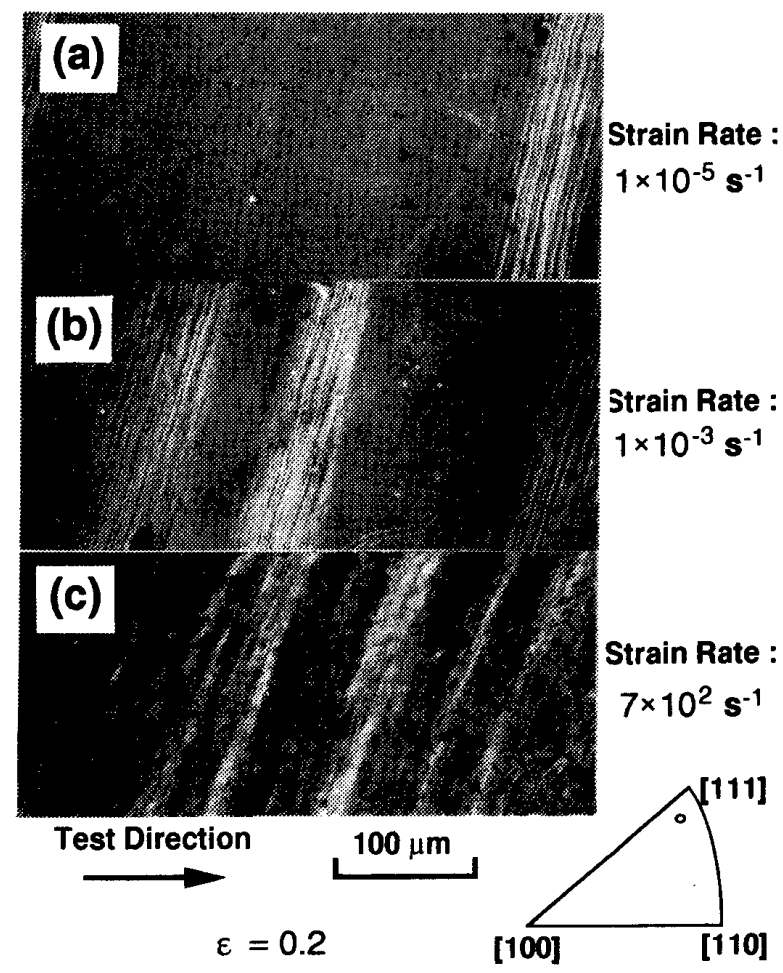

図 6 Uずみ 0.2 における単結晶 type A の表面の様子
5 に示す。この方位においても type A の場合と同様 に，ひずみ速度に依らず上に凸の放物線形状となって いる.また，ひずみ速度が高くなるに従って, 流動応力 は増加しており, 先の 2 種の単結晶と比較して, 低ひ ずみ速度でも明らかな応力の増加が認められる。

$3 \cdot 2$ すへり带の锶察 圧縮試験後, 試験片側面 を SEM により観察した. type A，B およびCの単結 晶をひずみ 0.2 まで圧縮したときの表面の様子を図 6 (a) 〜 (c) , 図 7 (a) 〜 (c) 抢よび図 $8(\mathrm{a}) \sim(\mathrm{c}) に$ 示す.ここで，(a)，(b)および(c)はそれぞれ，ひず み速度 $1 \times 10^{-5}, 1 \times 10^{-3}$ および $7 \times 10^{2} \mathrm{~s}^{-1}$ にて変形さ せた結果について示した. type Bの方位を有する単結 晶では，ひずみ速度によらず，すべり帯が一様に分布 している。ところが, type Aの方位を有する単結晶で は，ひずみ速度によらず，すべり帯が局所的に密集し ており，すべり帯の疎密領域を形成している。 また， type Cの方位を有する単結晶では，ひずみ速度によら ず，二重すべりがおこり，各すべり带の分布は一様に なっている.ここで注意を要するのは，このような 500 倍程度の観察では，1本とみられているすべり帯が, 実際には多数の単一すべりの集合体である(4)というこ とである。

また，すべての単結晶に共通して言えることは，ひ ずみ速度の増加とともに，そのすべり帯間隔が小さく

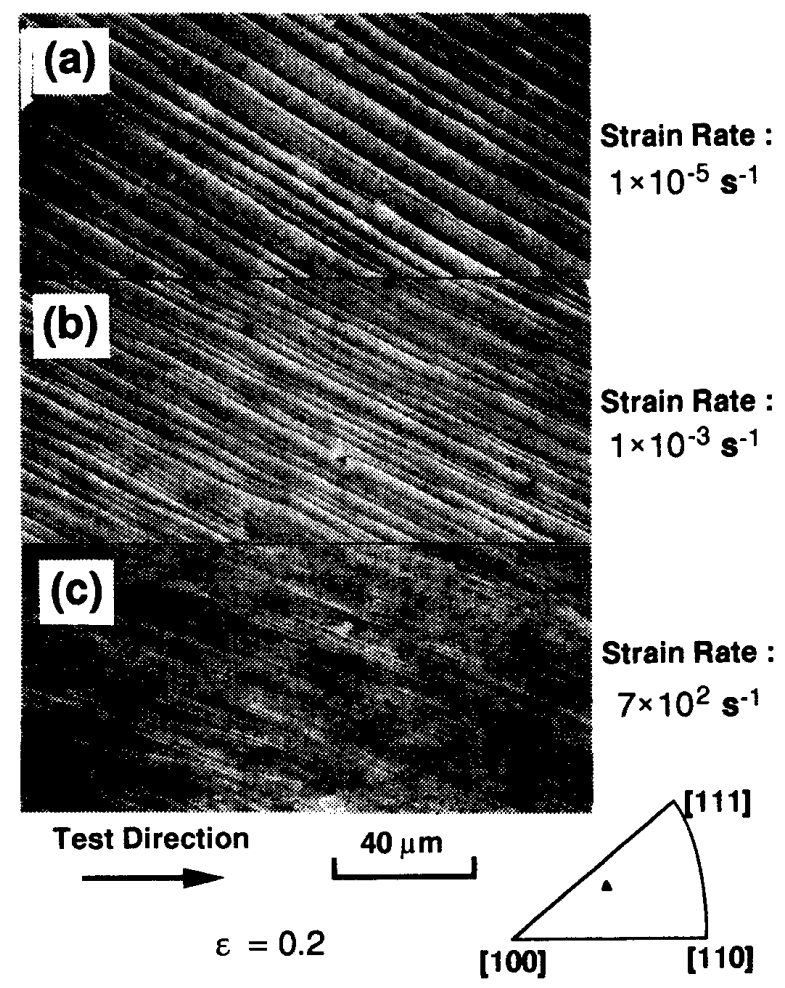

図 7 ひずみ 0.2 における単結晶 type B の表面の様子 
なっていること,および各すべり帯のコントラストが 弱くなっていることである，よって，ひずみ速度の高 低よりもむしろ, 結晶の方位に依存して，その変形機 構が大きく変化するものと思われる，ひずみ速度の高 低によるこれらのすべり帯の差異は，他の報告におい てもみられている(1)(2).

\section{4. 考察}

$4 \cdot 1$ 流動応力のひずみ速度依存性 一般に, ア ルミニウム等の面心立方金属の室温における強度は, ひずみ速度にそれほど大きく影響されないと言われて いる(5).ところが, 本研究で用いた高純度アルミニウ 厶単結晶では, 流動応力の高いひずみ速度依存性がみ られた。そこで, 前述の応力とひずみの関係をもとに して, 各単結晶の流動応力とひずみ速度の関係を調べ た結果を図 9 に示す。ここでは，例としてひずみ $0.1 に$ おける結果を示した。 type A および type Bには共通 した傾向がみられる，すなわち低ひずみ速度域ではひ ずみ速度が増加しても流動応力はわずかに増加する程 度である。ところが, 高ひずみ速度域ではひずみ速度 の増加にともない流動応力の急激な増加がみられる。 ただし，流動応力の絶対値は type Aの単結晶のほう が高くなっている。 また, type Cの単結晶に関しては 先の 2 種の単結晶とは異なる傾向がみられた。すなわ

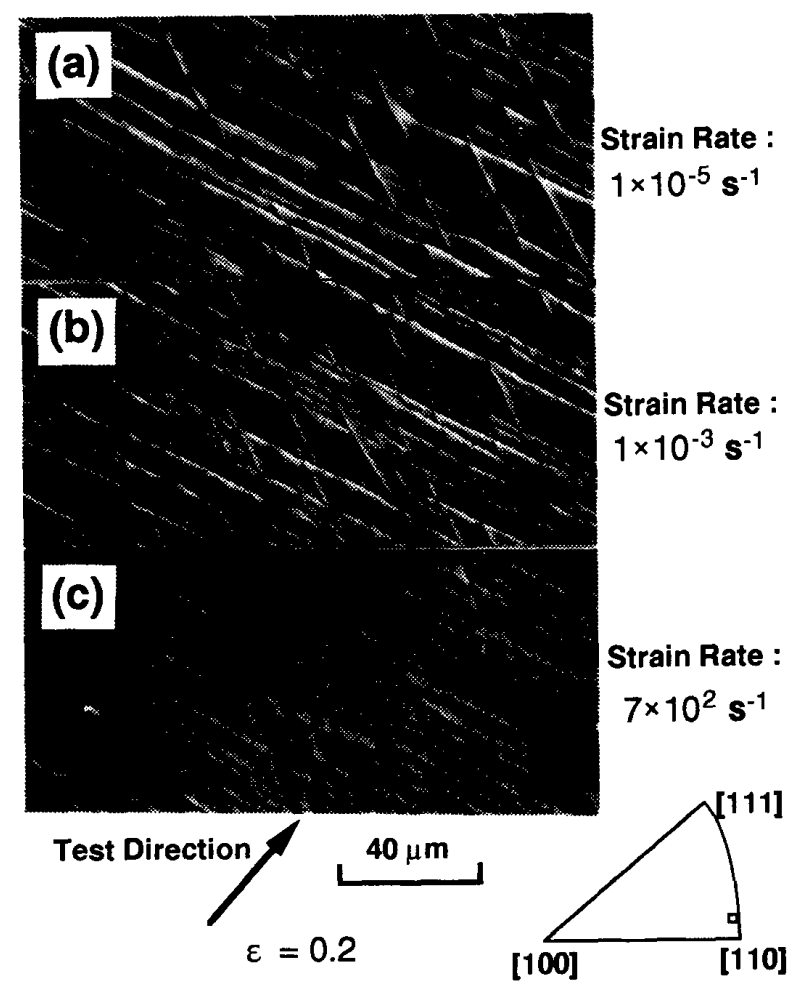

图 8 ひずみ 0.2 における単結晶 type C の表面の様子
ち，低ひずみ速度域においても，明確な流動応力のひ ずみ速度依存性がみられたことと，高ひずみ速度域に おける急激な応力の増加はみられなかったことであ る.

以上のことから，単一すべり系が支配的な，いわゆ る層状すべりが起こる方位の単結晶に関しては次のよ うな流動応力のひずみ速度依存性があるものと思われ る. (1)低ひずみ速度域では流動応力はほとんど変化せ ず，低いひずみ速度依存性を示すが，高ひずみ速度域 では，低ひずみ速度の場合の約 2 倍程度まで急激に流 動応力が増加し, 顕著なひずみ速度依存性を示す。(2) また，すべり带が一様に分布する方位の単結晶よりも， 疎と密な領域に分かれるような分布をするもののほう が流動応力の絶対值は高い.また，二重すべりが起こ る方位の単結晶に関しては, 以下のような流動応力の ひずみ速度依存性がみられた，低ひずみ速度域におい ても,ひずみ速度の増加とともに流動応力が増加する という明確なひずみ速度依存性がみられた。この現象 は単一すべり系が支配的な単結晶にはみられなかつ た。このようなひずみ速度依存性が現れた一因として 以下のようなことが考えられる. $3 \cdot 2$ 節の表面観察結 果からわかるように, 単一すべりが支配的な場合と二 重すべりが支配的な場合ともにひずみ速度の増加とと もにすべり帯の間隔は短くなっている。ここで, 単一 すべりが支配的な場合には, 変形とともに発生する各 転位は主として, 単一のすべり面上を移動するため相 互作用を起こしにくい，ところが，二重すべりが支配 的な場合には, 異なる二つのすべり面上で活動する転

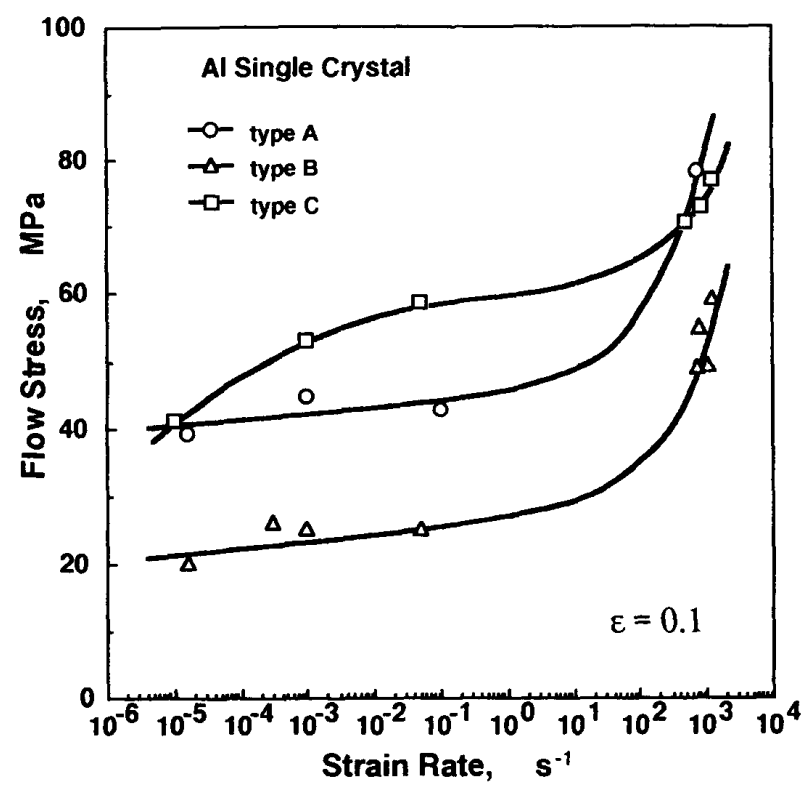

図 9 各単結晶の流動応力とひずみ速度の関係 
位が相互作用を起こしやすい，さらに，ひずみ速度の 増加とともにすべり帯の間隔は短くなってゆくため に, 相互作用を起こす頻度が高くなる.このため, 二重 すべりが起こる単結晶では, 低ひずみ速度域において もひずみ速度の増加にともなう, 流動応力の増加が明 確に現れたものと思われる。

4.2 すべり带間隔とひずみ速度の関係 本研究 に用いた単結晶では, 図6〜8からわかるように, ど の方位に関しても，ひずみ速度の増加とともにすべり 帯の間隔は小さくなる傾向がみられた。そこで, 単結 晶 type Bについて，ひずみ 0.2 の変形を与えた後に, 試験片側面の平均すべり帯間隔を求めた。平均すべり 帯間隔とひずみ速度の関係を図 10 に示す。ここでは, 参考のため同一のひずみにおける流動応力とひずみ速 度の関係も併せて示した。この図より，ひずみ速度の 増加とともにすべり帯間隔は減少するというひずみ速 度依存性が明らかになった。また，この図より，すべり が集中するすべり帯の間隔はひずみ速度の增加ととも にある一定値に収束するのではないかと思われる。そ のために高ひずみ速度で試験した場合には，単位面積 当たりのすべり帯の数が飽和してくるため, 限られた 数のすべり帯に変形が集中する．その結果, 変形とと もに発生する転位が集積しやすくなり,変形抵抗が増 加する，これは，高ひずみ速度域でひずみ速度の増加 とともに流動応力が顕著に増加するという実験事実に よく対応しているものと思われる.

\section{5. 結言}

方位の異なる高純度アルミニウム単結晶を広範囲に わたるひずみ速度域にて圧縮試験し，以下のような知 見を得た。

（1）変形後の表面観察により，方位に依存して, 単一すべりおよび二重すべりが起こることが確認され たままた，ひずみ速度の増加とともにすべり帯間隔は 小さくなり，各すべり帯のコントラストは弱くなる傾 向を示した。

（2）単一すべりが起こる方位の単結晶では, $10^{-1} \mathrm{~s}^{-1}$ 以下の低ひずみ速度域において，その流動応 力はわずかなひずみ速度依存性しか示さない。ところ が，二重すべりが起こる方位の単結晶では同様の低ひ ずみ速度域においても，流動応力は明確なひずみ速度 依存性を示す。また，単一すべりが起こる方位の単結 晶では，高ひずみ速度域において急激な応力の増加が

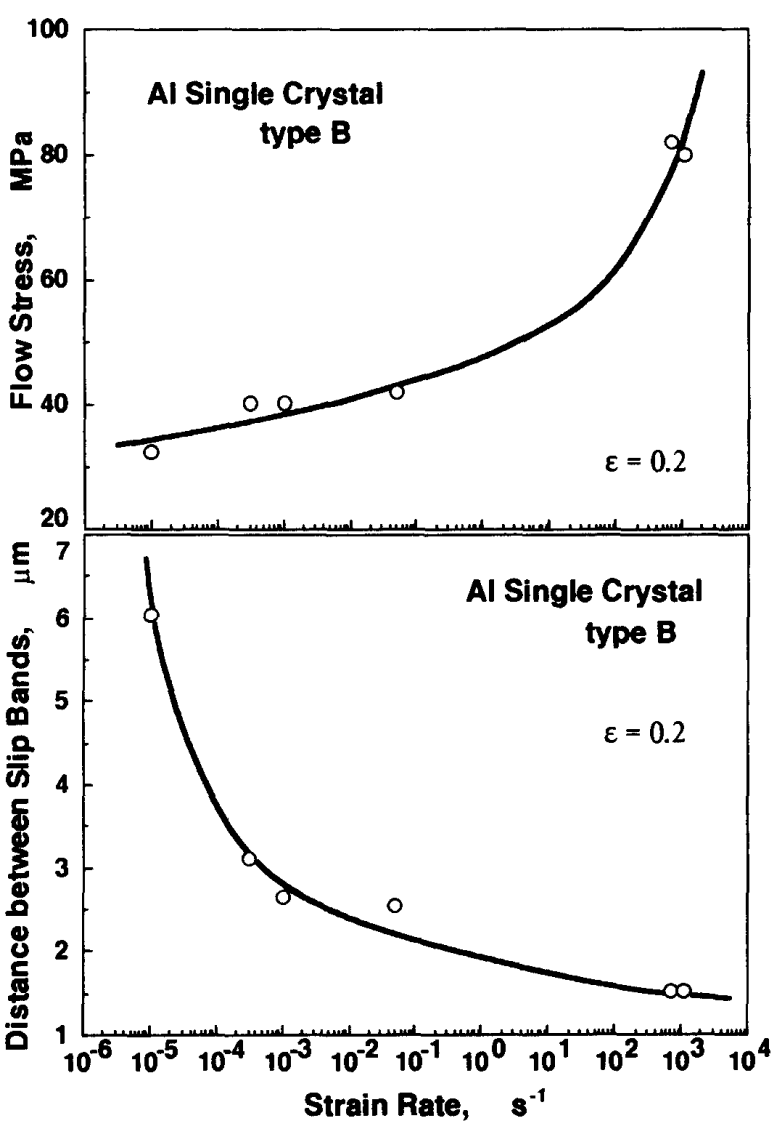

図 10 単結晶 type B における流動応力および平均すべ り帯間隔とひずみ速度の関係 $(\varepsilon=0.2)$

みられ，高いひずみ速度依存性を示した。

（3）均一に単一すべりが起こる方位の単結晶で は，そのすべり帯間隔は，ひずみ速度の増加とともに 小さくなるというひずみ速度依存性が確認された。

本研究を行うにあたって，素材の提供ならびに方位 解析にご協力下さった住友軽金属工業(株)技術研究所 の平野清一氏，松田眞一氏に深く感謝の意を表する. また，試験片の放電加工にご協力下さった，大阪市立 工業研究所の石川晧一氏, 杉岡正美氏に深く感謝の意 を表する。

\section{文献}

（1）作井・角間・森，日本金属学会誌，29（1965）, 903.

（2）吉田・永田, 日本金属学会誌, 30 (1966), 879.

(3) Lindholm, U. S. and Yeakley, L. M. , J. Mech. Phys. Solids, 13 (1965), 41

（4）日本金属学会編，転位論の金属学への応用，(1957)，83， 丸善。

（5）例えば, 作井・森，精密機械，31（1965)，525. 